\title{
WHEAT (Triticum L.) CULTIVARS FROM GRIN COLLECTION (USA) SELECTED FOR DURABLE RESISTANCE TO Septoria tritici AND Stagonospora nodorum BLOTCH
}

\section{T.M. KOLOMIETS, L.F. PANKRATOVA, E.V. PAKHOLKOVA}

All-Russian Research Institute of Phytopathology, Federal Agency of Scientific Organizations, 5, ul. Institute, pos. Bol'shie Vyazemy, Odintsovskii Region, Moscow Province, 143050 Russia, e-mail lomi1@yandex.ru, kolomiets@vniif.ru

ORCID:

Kolomiets T.M. orcid.org/0000-0002-1897-2380

The authors declare no conflict of interests

Received June 16, 2016

Pankratova L.F. orcid.org/0000-0001-7472-1079

\begin{abstract}
Septoria tritici blotch (STB) or Stagonospora nodorum blotch (SNB) are among the most harmful and economically significant diseases of wheat in the grain growing regions of the world, especially in the countries with a temperate climate. In epiphytotic years the losses from the disease can reach 30-40\%. In Russia the diseases holds a dominant position in a pathogenic complex of fungus diseases of grain crops. In this paper we first determined the parameters of partial resistance in the cultivars of wheat (genus Triticum) from the collection of the Germplasm Resources Information Network (GRIN, USA) using the stable strains of Septoria tritici and Stagonospora nodorum pathogens. The aim of our study was to select wheat varieties with long-term resistance to blotch based on field and laboratory tests. A long-term study (2009-2015) of the disease development on the wheat cultivars from GRIN Collection were conducted at artificial infection in infection nursery (Central region of Russia, Moscow Province). The samples studied belonged to various genetic groups. A total of 20 samples were diploids $(2 n=14), 409$ samples were tetraploids $(2 n=28), 1688$ samples were hexaploids $(2 n=42)$, and also 397 lines derived from crossing of Triticum aestivum with Aegilotriticum were tested. The area under disease progress curve was determined, and the index of resistance (IR) was calculated. The cultivars, that characterized by slow development of the disease in the field, i.e. with high-and middle IR, were selected for laboratory studies. The plants were grown in artificial climate chambers till the $3^{\text {rd }}$ leaf fully unfolded. Pieces of leaves were inoculated by a drop of spore suspension of S. tritici (4 isolates) or St. nodorum (4 isolates), 10 replications per each variety-topathotype combination. The samples were grouped according to the latent period length and size of infectious spots. As a result, 191 samples of T. aestivum subsp. aestivum and a sample of T. aestivum subsp. spelta with a high index of resistance to the disease were selected among hexaploid wheat; 16 samples were found in tetraploid wheat, including 8 samples of T. turgidum subsp. durum, 2 samples of T. turgidum subsp. turgidum, 3 samples of T. turgidum subsp. dicoccon, 3 samples of T. timopheevii subsp. timopheevii; and 4 samples were selected from diploid wheat T. monococcum subsp. aegilopoides. Eleven lines derived from crossing of T. aestivum and Aegilotriticum sp. showed the sloweddown in the disease development. The selected hexaploid wheat cultivars were mostly from North American ecology-geographical group of $T$. aestivum subsp. aestivum, including 77 cultivars from the USA and 18 - from Canada $(34.5 \%$ in total). Selected tetraploid wheat samples of T. turgidum subsp. durum were from North and Central America, and those of T. turgidum subsp. turgidum, T. timopheevii subsp. timopheevii and T. turgidum subsp. dicoccon from Europe and Asia. The samples from Iraq and Hungary with a high index of blotch resistance were found among diploid wheat T. monococcum subsp. aegilopoides. The synthetic lines of wheat from the USA and Mexico were also characterized by a slowed-down development of the disease. Thus the wheat cultivars with partial resistance have been revealed, including 10 cultivars with partial resistance to Septoria tritici blotch and 40 cultivars - to Stagonospora nodorum blotch. The accessions PI 494096 Tadinia, Cltr 17904 Owens, Cltr 15645 II-62-4 (USA), VIR 63915 Flame (England), Cltr 14492 Azteca, PI 520555 Alondora 'S' (Mexico), PI 404115 Timson (Australia), Cltr 11765 Chinese 166 (Germany), PI 422413 CNT 1 (Brazil), PI 168724 Benvenuto, Cltr 15378 Piamontes, PI 344468 Piamontes Inta (Argentina), PI 3065512944 (Romania), PI 355706 69Z5.715 (Azerbaijan), PI 355560 SK 1B (Switzerland), PI 94743290 (Russia) are of special interest for breeding as a source of long term resistance.
\end{abstract}

Keywords: Septoria tritici blotch, STB, Stagonospora nodorum blotch, SNB, partial re- 
sistance, long-term resistance, Triticum L., diploid, tetraploid and hexaploid wheat, synthetic lines, the Germplasm Resources Information Network (GRIN) Collection

Septoria blotch is one of the most dangerous and economically significant diseases of grain crops in the majority of regions with a temperate climate $[1,2]$. The greatest harmfulness of the disease was noted in France, Great Britain, Germany, Poland, Belgium, Czech Republic, the Netherlands, in Scandinavian countries (Norway, Sweden, and Finland), Lithuania, and Latvia [3-7). Cases of Septoria blotch were recorded in North Africa (Tunisia, Algeria, Morocco, Ethiopia) and Australia, Northern Caucasia (Georgia), North America (the USA, Canada) and South America (Mexico, Argentina) [8-15]. In Russia, Septoria blotch holds a dominant position in a pathogenic complex of fungus diseases of wheat plantings. The disease poses the highest priority danger in Central, Southern, North Caucasian, North-Western, Privolzhsky, and Siberian Federal regions [16-18]. In epiphytotic years, the crop losses from the disease can reach 20-40\% [19-23]. Septoria blotch reduces the photosynthetic activity of plants and causes the ear malformation. The assimilation surface of leaves decreases, the stems are die-back and folded (as a result of severe node damages), early ripening and shortfall of grains are observed. In case of severe damage of crops, Septoria blotch may cause seedlessness and death of individual plants. If the disease appears later the grain yield diminishing does not generally exceed 5$7 \%$ [24-26]. The Septoria blotch pathogens can affect all the aboveground organs of plants. There are about 16 names of these fungi in the literature, but their taxonomy generates a lot of differences. The best known species now are Septoria tritici Rob. Et Desm.; Stagonospora nodorum (Berk.) E. Castellani and E.G. Germano and Stagonospora avenae Bissett f. sp. triticea T. Johnson [25].

There is almost no wheat breeding for resistance to Septoria blotch in our country, although the disease has been starting to spread throughout Russia since early 1970s, and currently it is present in nearly every region where spring and winter wheat is cultivated. The development of resistant cultivars requires donors, the sources of resistance genes, which can be searched for only among varieties of world collections. The most long-lasting protection against Septoria blotch is provided by partially resistant varieties which are characterized by slower development of the disease in field, can reduce the probability of epiphytotics and extend the duration of resistance retention in a cultivar [25, 27].

In this paper, we have determined for the first time the parameters of partial resistance in the cultivars of wheat from the collection of the Germplasm Resources Information Network (GRIN, USA) using the stable strains of Septoria tritici and Stagonospora nodorum pathogens.

The aim of our study was to select wheat cultivars with the durable resistance to Septoria blotch based on field and laboratory tests.

Technique. Dynamics of Septoria blotch development in wheat samples (genus Triticum) from the GRIN collection (Germplasm Resources Information Network, USA) was studied in 2009-2015 in an infection nursery located at the Central Region of Russia (Moscow Province, Odintsovo Region, trial fields of All-Russian Research Institute of Phytopathology, ARRIP). The study was conducted in 2117 wheat samples from various genetic groups, including 20 diploids $(2 n=14), 409$ tetraploids $(2 n=28), 1688$ hexaploids $(2 n=42)$, and also 397 selection samples derived from crossing of Triticum aestivum with Aegilotriticum sp.

Area under disease progress curve (ADPC) was determined by the method of D.A. Johnson et al. [28] based on results of 5 and more measurements of Septoria blotch affection intensity for plants during the growing season:

$$
\mathrm{S}=1 / 2\left(\mathrm{x}_{1}+\mathrm{x}_{2}\right)\left(\mathrm{t}_{2}-\mathrm{t}_{1}\right)+\ldots+\left(\mathrm{x}_{n-1}+\mathrm{x}_{n}\right)\left(\mathrm{t}_{n}-\mathrm{t}_{n-1}\right)
$$

where $\mathrm{S}$ is the area under disease progress curve; $n$ is the number of measure- 
ments; $\mathrm{x}_{1}, \mathrm{x}_{2}, \mathrm{x}_{n}$ are a degree of the disease development at the time of the 1st, 2nd and last measurements, respectively, \%; $\left(\mathrm{t}_{2}-\mathrm{t}_{1}\right)$ is the time interval between the $2 \mathrm{nd}$ and the 1st measurements, days; $\left(\mathrm{t}_{n}-\mathrm{t}_{n-1}\right)$ is the time interval between the last and second to last measurements, days.

Index of resistance (IR) was calculated by the formula proposed by A.A. Makarov et al. [29] as a ratio of the ADPC for the cultivar tested to that for the susceptible control: $\mathrm{IR}=\mathrm{ADPC}_{\text {cultivar }} / \mathrm{ADPC}_{\text {control }}$. Based on the IR value, the cultivars were conditionally divided into 4 groups: cultivars having high (0.10-0.35), medium (0.36-0.65), and low (0.66-0.80) IR, and highly susceptible cultivars (IR >0.81). The cultivars characterized by slower development of the disease in the field conditions, i.e. those having the high and medium IR, were selected for laboratory experiments.

Parameters of quantitative resistance to Septoria tritici pathogen (latent period and size of infectious spots) were studied in 39 wheat samples, and those to Stagonospora nodorum - in 60 wheat samples. The susceptible Priokskaya cultivar was used as a control. The pathogen strains were obtained from the National Collection of phytopathogenic microorganisms and varieties of plants identifying pathogenic strains of microorganisms (ARRIP).

The selected plants were grown in artificial climate chambers till the 3rd leaf fully unfolded. A leaf was cut into $9-10 \mathrm{~cm}$ long pieces and placed in trays onto filter paper wetted with aqueous solution of benzimidazole $(0.4 \mathrm{~g} / \mathrm{l})$. The pieces of leaves were inoculated by a drop of spore suspension of each of $S$. tritici isolates $\left(\mathrm{V}-35 / \mathrm{ChI} 1,5 / 23,5 / 8,5 / 9 ; 10^{7}\right.$ spores $\left./ \mathrm{ml}\right)$ or St. nodorum isolates (R-8, $\mathrm{V}-81, \mathrm{~V}-28 / \mathrm{KG}_{3}$, NAlt-1; $10^{6}$ spores $\left./ \mathrm{ml}\right), 10$ replications per each variety-topathotype combination.

According to latent period and size of infectious spots, the varieties were grouped as follows: I - varieties with small infectious spots and long latent period; II - varieties with small infectious spots and short latent period; III - varieties with large infectious spots and long latent period; IV - varieties with large infectious spots and short latent period. The varieties with a long latent period included those for which it lasted for or longer than 15 and 5 days for $S$. tritici and St. nodorum, respectively, and the varieties with a short latent period included those for which it lasted for less than 15 and 5 days. Spots with the area of $<20$ $\mathrm{mm}^{2}$ were considered small, and those of $>20 \mathrm{~mm}^{2}$ were referred to large ones.

Statistical processing was carried out by the analysis-of-variance method using the program developed at All-Russian Research Institute of Phytopathology (version 1.02.1995, № 006). Tables include mean values and LSD95.

Results. Based on findings of multi-year research, wheat cultivars and hybrid forms derived from crossing of T. aestivum with Aegilotriticum sp. showing different rates of Septoria blotch development have been identified. The most long-lasting protection was provided by cultivars with the high index of resistance (i.e. partially resistant to the disease) characterized by slower development of Septoria blotch under field conditions.

Wheat cultivars with the high IR were selected from various genetic groups taking into account their origin. As a result, the studied samples were distributed into 10 ecology-geographical groups according to N.I. Vavilov's classification $[30,31]$.

The maximum number of samples $(85.7 \%)$ with the high index of resistance was identified in cultivars of T. aestivum subsp. aestivum (Table 1).

The majority $(34.5 \%)$ of the studied hexaploid wheat cultivars that demonstrated resistance originated from the North American ecogeographical group (species T. aestivum subsp. aestivum): high IR was characteristic of 77 varieties from the USA and 18 ones from Canada (see Table 1). They were mainly se- 
lection samples, as well as cultivars Chaparral, Minnpro, Anderson (the USA) and Agatha (Canada). Anderson and Agatha cultivars which demonstrated the high IR to Septoria blotch for 3 and more years of studies were of particular interest.

1. Wheat cultivars from the collection of the Germplasm Resources Information Network (GRIN, the USA) with the high index of resistance to Septoria blotch (infection nursery, Central Region of Russia, Moscow Province, 2009-2015)

\begin{tabular}{l|l|l|l}
\hline $\begin{array}{l}\text { Ecogeographical } \\
\text { group }\end{array}$ & Country & $\begin{array}{l}\text { Number } \\
\text { of culti- } \\
\text { vars }\end{array}$ & Name \\
\hline
\end{tabular}

North American USA

Canada

Mexico

Brazil

South American

Argentina

East Asian

Mediterranean

South-Western Asian

South Asian

Australian

African

Total

West European

North American

191

Triticum aestivum subsp. aestivum $(2 n=42)$

$77 \quad$ N No. 1226; N No. 1121; N No. 1265; Rival; N 1827; II-36-67; 1415 A-1-1-1-1; Ns. 3880.227; Ns. 3880.127; II-52-238; ND 364; Chaparral; II-56-10; II-54-89; II54-102; II-54-1; II-58-51; II-60-115; II-59-11; II-6251; II-62-48; II-62-15; II-62-69; II-62-65; II-62-76; II62-77; II-62-79; II-62-75; II-62-82; II-62-81; II-62-83; II-62-84; II-62-25; II-54-79; II-62-49; II-62-32; II-6231; II-60-222; II-61-1; II-61-15; II-62-71; II-60-220; II-60-218; II-62-72; II-62-35; II-62-20; II-54-46; II-5632; II-56-29; II-56-33; II-58-15; II-58-57; II-58-14; II56-12-7; II-60-100; II-60-46; II-60-126; II-60-130; II52-324; CI 15756; ND 466-2; ND 468; Frohberg 12107; MN 6796; MN 6864; MN 6955S; MN 6983S; MN 7570; ND 573; ND 599; MN 7444; MN 7533; ND 617; Minnpro; Cltr 15645; Anderson; WA 6101

18 RL 988; RL 2520; RL 4137; Agatha; RL 4110; RL 4151; RL 4170; RL 4203; RL 4204; 60 GRR 92; Q 254-43; Q 2331-34; RL 6003; RL 6005; RL 6008; RL 6009; RL 6010, P8917-B4D4

36 CI 2817; II-1776-2C; II-3962-2H-2Y-3C-1Y; VI-13649-6H-1R; Huamantla Rojo; II-7242-5C-1H-2R-1M; II-7232-17R-1M-1B-2M; II-7527-5M-2R-5M-1R; II7740-26-2H-1R-4M; II-8192-2R-2M-1R-4M; II-84954Y-9C-2Y-2C-1Y-2C-1Y; II-8523-11M-1R-4M; 87384R-5M-1R-1M-1R; P-9897-8T-2B-1T-1B; P-9916-9T1B-2T-1B; P-11380-1B-7T-1B; P-11380-1B-7T-1B; II11996-4R-5M-1R; JARAL 66; Bajio; Potam 70; II19008-52M-6Y-3M-3Y-2C; II-19005-23M-3Y-3M-2Y2C; II-19865-58M-100Y-104C; II-19021-4M-3Y-102M2C; II-19008-83M-4R-4C-2Y-4C; D 19329-28M-11Y; Alondra 'S'; Cocora-Que F75; Mor 'S'; SWM 4127-1Y1M-4Y-2M-1Y-OM; Bobwhite 'S'; Veery No. 3; Bobwhite 'S'; Alondra 'S'; II-1462-2C-2C-15C

BH 941; CNT 1; Trareano; 16-52-2, BH 2845; Itapeva; Colotano; 266/51

Americano; IF 1054; Klein H211-t-1422; Benvenuto Inca; Benvenuto 3085; La Prevision 25; 38 M.A.; Klein Lucero; Piamontes; D.I.V. 6656; I-1055; Magnif 142; Piamontes Inta; Klein Impacto; Vivela Mar; Taganrog Buck Balcarse; Mole II; 1352

Peru $\quad 3 \quad$ Mult 757; Mult 760; Mult 764

Germany $\quad 1 \quad$ Chinese 166

Belgium 1 ALBA

Macedonia $\quad 1 \quad \mathrm{I} / 24$

Czechoslovakia 2 Dobrovicka Drogerowa B I 32; Stupicka Bastard

Bulgaria $\quad 2$ Bogdan, Experiment station no.85

Portugal $\quad 3$ Richelle Blanche Hative; Portugues; WS-9

China $\quad 13 \quad 3867$; CI 8328; Chiu mai; 7045; 7049; 848; 7177; 7227;

7329; I13; 357; ST-56; Daqingshan No. 4

Turkey $\quad 1 \quad 1403$

Iran $158 \mathrm{e}$

Afghanistan $\quad 2$ BlackShanazi; Sirhosha

Nepal $\quad 1 \quad 57-336$

Australia $\quad 2$ AB 21/10-1-1-2; Timson

Ethiopia $\quad 1$ ELS 6404-26

Triticum aestivum subsp. spelta $(2 n=42)$

Spain $\quad 1 \quad 69 Z 6.886$

USA Triticum turgidum subsp. durum $(2 n=28)$

$\begin{array}{lll} & \text { ND 63-36 } \\ \text { Canada } & 1 & \end{array}$ 
South-Western Asian

West European

West European

South-Western Asian

West European

Mediterranean

South-Western Asian

West European

North American

Central American

Total
Triticum turgidum subsp. turgidum $(2 n=28)$

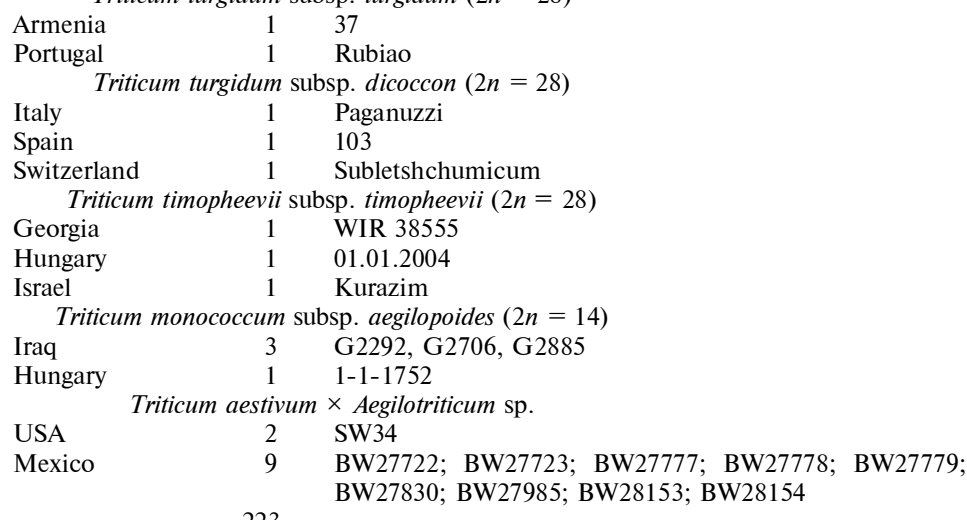

The Central American group included cultivars from Mexico and Brazil. Among Mexican samples we have selected 36 cultivars having high IR. Slower development of the disease in the samples originated from Brazil (BH 941, CNT 1, Trareano, 16-52-2, BH 2845) was noted throughout multi-year studies. Eighteen cultivars with the high IR from Argentina and three lines from Peru have been identified among 54 studied samples from South America. Ten similar cultivars have been found out in West European countries, and 13 samples from China have been revealed in the East Asian ecogeographical group (see Table 1).

The Mediterranean, South-Western Asian, South Asian, Australian and African ecogeographical groups appeared to be represented by a small number of $T$. aestivum subsp. aestivum cultivars. However, we succeeded in finding samples with high partial resistance to the disease among them, i.e. sample 1403 (Turkey), 158e (Iran), Black Shanazi and Sirhosha (Afghanistan), 57-336 (Nepal), AB 21/10-1-1-2 and Timson (Australia), ELS 6404-26 (Ethiopia). In the genetic group of hexaploid wheat, sample 69Z6.886 (Spain) referred to T. aestivum subsp. spelta species has been selected (see Table 1).

Among tetraploid wheat cultivars of T. turgidum subsp. durum, we have revealed 16 ones having the high IR (originating generally from North and Central America). Two European samples were identified in turgidum subsp. turgidum group, three European samples were found among $T$. timopheevii subsp. timopheevii forms, as well as three ones - among T. turgidum subsp. dicoccon (see Table 1).

Cultivars with high index of resistance to Septoria blotch included 4 diploid wheat samples of $T$. monococcum subsp. aegilopoides originated from Iraq and Hungary. Slower development of the disease was also characteristic of synthetic lines of wheat from USA and Mexico (see Table 1).

When assessing the quantitative resistance of wheat cultivars to Septoria blotch pathogens $S$. tritici and St. nodorum, the samples were divided into four groups. Group I cultivars, the slower development of the disease in which is defined by a longer latent period and smaller size of infectious spots as compared to those in the susceptible control, attract the most interest for selection. Among the studied samples from the GRIN collection, we have not found any cultivars belonging to group I by their resistance to $S$. tritici. Group I by resistance to St. nodorum included 13 cultivars (Table 2).

The infection development in group II cultivars was slowed down due to the reduction in sizes of infectious spots. Group II by resistance to $S$. tritici in- 
cluded 8 cultivars, and by resistance to St. nodorum there were 8 cultivars as well from the GRIN collection (see Tables 2, 3).

2. Wheat cultivars from the collection of the Germplasm Resources Information Network (GRIN, USA) partially resistant to Stagonospora nodorum

\begin{tabular}{|c|c|c|c|c|}
\hline $\begin{array}{l}\text { № as per the } \\
\text { GRIN catalog }\end{array}$ & Cultivar & Origin & Spot size, $\mathrm{mm}^{2}$ & $\begin{array}{l}\text { Latent period, } \\
\text { days }\end{array}$ \\
\hline \multicolumn{5}{|c|}{ Group I } \\
\hline PI 520555 & Alondora 'S' & Mexico & 18.32 & 7.00 \\
\hline PI 422413 & CNT 1 & Brazil & 13.86 & 6.50 \\
\hline VIR 63915 & Flame & Great Britain & 15.72 & 6.50 \\
\hline PI 404115 & Timson & Australia & 12.03 & 6.25 \\
\hline PI 494096 & Tadinia & USA & 13.35 & 6.25 \\
\hline PI 168724 & Benvenuto & Argentina & 11.60 & 5.50 \\
\hline PI 306551 & 2944 & Romania & 13.30 & 5.50 \\
\hline PI 355706 & $69 \mathrm{Z} 5.715$ & Azerbaijan & 13.70 & 5.50 \\
\hline Cltr 15645 & II-62-4 & USA & 16.56 & 5.50 \\
\hline PI 344468 & Piamontes Inta & Argentina & 16.88 & 5.50 \\
\hline Cltr 17904 & Owens & USA & 17.13 & 5.50 \\
\hline PI 355560 & SK 1B & Switzerland & 10.60 & 5.30 \\
\hline PI 94743 & \multicolumn{3}{|c|}{ Group II } & 5.25 \\
\hline PI 190974 & Aristato Blanco & Italy & 11.00 & 4.50 \\
\hline PI 191353 & Novokrymka 204 & Ukraine & 15.20 & 4.50 \\
\hline PI 341803 & WIR43065 & France & 15.50 & 4.50 \\
\hline PI 345242 & 241-VII/4 & Macedonia & 12.90 & 4.30 \\
\hline PI 300991 & Kurazim & Israel & 13.40 & 4.30 \\
\hline PI 427867 & G2697 & Iraq & 12.83 & 4.25 \\
\hline PI 418584 & WIR 38555 & Georgia & 18.40 & 4.00 \\
\hline PI 290518 & 01.01 .2004 & $\begin{array}{l}\text { Hungary } \\
\text { Group III }\end{array}$ & 19.13 & 4.00 \\
\hline Cltr 12536 & Anderson & USA & 33.50 & 7.30 \\
\hline VIR 64130 & Warigal Dagger & Australia & 36.50 & 7.30 \\
\hline PI 168725 & Benvenuto 3085 & Argentina & 48.00 & 7.30 \\
\hline PI 338913 & Azteca & Mexico & 66.40 & 7.30 \\
\hline PI 168724 & Benvenuto INCA & Argentina & 56.50 & 6.80 \\
\hline PI 278222 & Gambridge Rivet & Great Britain & 29.00 & 6.50 \\
\hline PI 604225 & KS96WGRC40 & USA & 29.10 & 6.30 \\
\hline Cltr 13113 & Kansas № 26365 & USA & 42.20 & 6.30 \\
\hline Cltr 15378 & Piamontes & Argentina & 24.58 & 6.25 \\
\hline Cltr 14465 & Kansas № 594-2 & USA & 34.00 & 6.00 \\
\hline Cltr 14492 & Azteca & Mexico & 22.16 & 6.00 \\
\hline PI 214401 & Veranopolis & Brazil & 33.67 & 6.00 \\
\hline PI 520552 & Bobwhite 'S' & Mexico & 28.66 & 5.50 \\
\hline Cltr 12053 & Cadet & USA & 30.58 & 5.50 \\
\hline PI 422273 & Alondra 'S' & Mexico & 24.28 & 5.50 \\
\hline Cltr 11765 & Chinese 166 & Germany & 39.28 & 5.50 \\
\hline PI 348702 & $69 \mathrm{Z} 6.886$ & Spain & 26.68 & 5.00 \\
\hline PI 479692 & $\mathrm{~K}-20$ & Republic of South Africa & 35.00 & 5.00 \\
\hline Cltr 64135 & IW 562 & Australia & 52.00 & 5.00 \\
\hline $\mathrm{LSD}_{95}$ & & & 13.86 & 0.92 \\
\hline
\end{tabular}

3. Wheat cultivars from the collection of the Germplasm Resources Information Network (GRIN, the USA) partially resistant to Septoria tritici

\begin{tabular}{|c|c|c|c|c|}
\hline $\begin{array}{l}\text { № as per the } \\
\text { GRIN catalog }\end{array}$ & Cultivar & Origin & Spot size, $\mathrm{mm}^{2}$ & $\begin{array}{l}\text { Latent period, } \\
\text { days }\end{array}$ \\
\hline \multicolumn{5}{|c|}{ Group II } \\
\hline Cltr 15378 & Piamontes & Argentina & 20.00 & 14.50 \\
\hline PI 433753 & Gambridge 010 & Mexico & 16.60 & 8.00 \\
\hline PI 648860 & BW 28154 & Mexico & 18.30 & 8.00 \\
\hline PI 191204 & Rubiao & Portugal & 13.50 & 7.75 \\
\hline Cltr 11765 & Chinese 166 & Germany & 11.50 & 7.25 \\
\hline PI 189631 & Trareano & Brazil & 12.90 & 7.75 \\
\hline PI 352061 & Klein Inpacto & Argentina & 15.00 & 7.25 \\
\hline PI 422413 & CNT 1 & $\begin{array}{l}\text { Brazil } \\
\text { Grou p III }\end{array}$ & 14.00 & 7.00 \\
\hline PI 338913 & Azteca & Mexico & 25.00 & 15.00 \\
\hline PI 520555 & Alondora 'S' & Mexico & 36.30 & 15.00 \\
\hline $\mathrm{LSD}_{95}$ & & & 21.10 & 1.94 \\
\hline
\end{tabular}


Group III included the cultivars that provided slower development of the disease due to longer latent period. Cultivars Azteca and Alondora ' $S$ ' belonged to them by resistance to $S$. tritici, and 19 cultivars were included due to resistance to St. nodorum (see Table 2). Susceptible cultivars, the latent period and size of infectious spots in which were consistent with or exceeded the similar parameters in the susceptible control, were referred to group IV. This group included 30 forms that demonstrated weak susceptibility to $S$. tritici pathogen in field experiments, and 20 forms showed weak susceptibility to St. nodorum.

Thus, as a result of multi-year studies of samples from the GRIN collection (Germplasm Resources Information Network, USA), wheat cultivars ensuring partial resistance of plants to Septoria blotch due to the extended latent period and reduced size of infectious spots, as well as capable of limiting the epiphytotic development of the disease, have been selected. They include 10 cultivars partially resistant to Septoria tritici pathogen, and 40 cultivars partially resistant to Stagonospora nodorum. The varieties most valuable for selection of cultivars with a durable resistance to Septoria blotch are Tadinia (PI 494096), Owens (Cltr 17904), II-62-4 (Cltr 15645) originating from the USA, Flame (VIR 63915) from Great Britain, Azteca (Cltr 14492), Alondora 'S' (PI 520555) from Mexico, Timson (PI 404115) from Australia, Chinese 166 (Cltr 11765) from Germany, CNT 1 (PI 422413) from Brazil, Benvenuto (PI 168724), Piamontes (Cltr 15378), Piamontes Inta (PI 344468) from Argentina, 2944 (PI 306551) from Romania, 69Z5.715 (PI 355706) from Azerbaijan, SK 1B (PI 355560) from Switzerland, and 290 (PI 94743) from Russia.

\section{REFERENCES}

1. Ponomarenko A., Goodwi n S.B., Ke ma G. Septoria tritici blotch (STB). The Plant Health Instructor, 2011 (doi: 10.1094/PHI-I-2011-0407-01).

2. B row n J.K.M., A r rai a no L.S. Association genetics of resistance to Septoria tritici blotch in north-west European wheat cultivars and breeding lines, and implications for resistance breeding. $8^{\text {th }}$ International Symposium on Mycosphaerella and Stagonospora diseases of Cereals. Book of Abstracts. Mexico city, Mexico, 2011: 48.

3. Wi i k L. Control of fungal diseases in winter wheat. Evaluation of long-term field research in southern Sweden. Acta Universitatis agriculturae Sueciae, 2009, 97: 3-45.

4. Suffert F., S a che I., La n no u C. Assessment of quantitative traits of aggressiveness in Mycosphaerella graminicola on adult wheat plants. Plant Pathol., 2013: 62: 1330-1341 (doi: 10.1111/ppa.12050).

5. Jørgensen L.N., Hovmøller M.S., Hansen J.G., Lassen P., Clark B., B ayles R., Rodemann B., Flath K., Jahn M., Goral T., Czembor J.J., Cheyron P., Maumene C., De Pope C., Ban R., Cordsen Nielsen G., B e rg G. IPM strategies and their dilemmas including an introduction to www.eurowheat.org. Journal of Integrative Agriculture, 2014, 13: 265-281 (doi: 10.1016/S2095-3119(13)60646-2).

6. Arrai a no L.S., Kirby J., B row n J.K.M. Cytogenetic analysis of the susceptibility of the wheat line Hobbit sib (Dwarf A) to Septoria tritici blotch. Theor. Appl. Genet., 2007, 116(1): 113-122 (doi: 10.1007/s00122-007-0651-9).

7. Arrfiano L.S., Braiding P.A., Debryver F., Brown J.K.M. Resistance of wheat to septoria tritici blotch (Mycosphaerella graminicola) and associations with ideotype and the 1BL-1RS translocation. Plant Pathol., 2006, 55: 54-61 (doi: 10.1111/j.1365-3059.2005.01319.x).

8. M c Do nald M.C., M c D o nald B.A., S olo mo n P.S. Recent advances in the Zymoseptoria tritici-wheat interaction: insights from pathogenomics. Front. Plant Sci., 2015, 6: 102 (doi: 10.3389/fpls.2015.00102).

9. Ra ma n H., Milgat e A. Molecular breeding for Septoria tritici blotch resistance in wheat. Cereal Res. Commun., 2012, 40(4): 451-466 (doi: 10.1556/CRC.40.2012.4.1).

10. Takele A., Le ncho A., Getane h W/Ab, Hailu E., Kass a B. Status of wheat Septoria leaf blotch (Septaria tritici Roberge in Desmaz) in South West and Western Shewa Zones of Oromiya Regional State, Ethiopia. Research in Plant Sciences, 2015, 3(3): 43-48.

11. Si mo n M.R., C o rdo C.A., C a stillo N.S., Struik P.C., B or ne r A. Population structure of Mycosphaerella graminicola and location of genes for resistance to the pathogen: Recent advances in Argentina. International Journal of Agronomy, 2012, 2012: Article ID 680275, (doi: 10.1155/2012/680275). 
12. S a i d A. Epidemics of Septoria tritici blotch and its development over time on bread wheat in Haddiya-Kambata Area of Southern Ethiopia. Journal of Biology, Agriculture and Healthcare, 2016, 6(1): 47-57.

13. S ingh P.K., Duveiller E., S ingh R.P., Singh S., Herrera-Foessel S.A., Huerta-Espino J., Manes Y., Bonnett D., Dreisigasker S. Characterization of CIMMYT germplasm for resistance to Septoria diseases of wheat. g $^{\text {th }}$ International Symposium on Mycosphaerella and Stagonospora diseases of Cereals. Book of Abstracts. Mexico city, Mexico, 2011: 55 .

14. S i mo n M.R., P e re 110 A.E., Cordo C.A., Larran S., van de r Putten P.E.L., Struik P.C. Association between Septoria tritici blotch, plant height, and heading date in wheat. Agron. J., 2005, 97(4): 1072-1081 (doi: 10.2134/agronj2004.0126).

15. Zhang X., Haley S.D., Jin Y. Inheritance of Septoria tritici blotch resistance in winter wheat. Crop Sci., 2001, 41: 323-326 (doi: 10.2135/cropsci2001.412323x).

16. S a ni n S.S., S a n i n a A.A. Septorioz pshenitsy. Diagnostika, fitosanitarnye nablyudeniya, upravlenie zashchitoi rastenii [Septoria leaf blotch in wheat - indication, survey, control of plant protection]. Moscow, 2013 (in Russ.).

17. Sanin S.S., Sanina A.A., Motovilin A.A., Pakholkova E.V., Korne va L.G., Z ho khova T.P., P oly a kova T.M. Zashchita i karantin rastenii, 2012, 4: 61-82 (in Russ.).

18. Pakholkova E.V., S a l'nikova N.N., Kurkova N.A. Genetic structure of regional populations of Mycosphaerella graminicola (Septoria tritici), the septoria leaf blotch agent of wheat. Agricultural Biology, 2016, 51(5): $722-730$ (doi: 10.15389/agrobiology.2016.5.722eng).

19. Kolomiets T.M., Pankratova L.F., Skat e nok O.O., Pakholkova E.V. Zashchita i karantin rastenii, 2015, 7: 44-46 (in Russ.).

20. Pakholkova E.V., S a l'nikova N.N., Aki mova E.A., S a n i na A.A. Materialy III Mezhdunarodnogo mikologicheskogo foruma «Sovremennaya mikologiya $v$ Rossii», tom 5 [Proc. III Int. Forum «Present state of mycology in Russia»]. Moscow, 2015, V. 5: 107-108 (in Russ.).

21. P a k h o l k o v a E.V. Zashchita $i$ karantin rastenii, 2015, 3: 39-40 (in Russ.).

22. Z e l e n e va Yu.V. Vestnik Tambovskogo universiteta. Seriya: Estestvennye i tekhnicheskie nauki, 2008, 13(5): 333-337 (in Russ.).

23. S a $n$ i n S.S., N a z a rova L.N. Zashchita i karantin rastenii, 2010, 2: 70-80 (in Russ.).

24. K o c horov, A.S., S a g i t o v A.O., A u b a k i rova A.T. Zashchita $i$ karantin rastenii, 2013, 9: 44-45 (in Russ.).

25. Kolomiets T.M., Pakholkova E.V., D ubovay a L.P. Otbor iskhodnogo materiala dlya sozdaniya sortov pshenitsy $s$ dlitel'noi ustoichivost'yu $k$ septoriozu. Metodicheskie ukazaniya [Selection of donor plants for breeding wheat varieties with durable leaf blotch resistance: recommendations]. Moscow, 2017 (in Russ.).

26. Giligan C.A. Sustainable agriculture and plant diseases: An epidemiological perspective. Philosophical Transactions of The Royal Society B Biological Sciences, 2008, 363(1492): 741-59 (doi: 10.1098/rstb.2007.2181).

27. B ockus W.W., D e Wolf E.D., Gill B.S., Jardine D.J., Stack J.P., B ow d e n R.L., F ritz A.K., M a rti n T.J. Historical durability of resistance to wheat diseases in Kansas. Plant Health Progress, 2011, August: 2 August 2011 (doi: 10.1094/PHP-2011-0802-01-RV).

28. Johnson D.A., Wilcoxs o n R.D. A table of areas under disease progress curves. Texas Agric. Exp. Stn. Tech. Bull., 1981, 1337: 2-10.

29. Makarov A.A., S trizhekozin Yu.A., S olom at in D.A., De mi cheva T.A., $\mathrm{Kukhtina}$ A.V. V sbornike: Immunitet sel'skokhozyaistvennykh kul'tur $k$ vozbuditelyam gribnykh boleznei [In: Crop immunity to fungal diseases]. Moscow, 1991: 105-110 (in Russ.).

30. V a vilov N.I. Uchenie ob immunitete rastenii $k$ infektsionnym zabolevaniyam. Tom 1 [Doctrine of plant immunity to infectious diseases. V. 1]. Leningrad, 1967 (in Russ.).

31. Vavilov N.I. Proiskhozhdenie $i$ geografiya kul'turnykh rastenii [Geographic distribution of crop origins]. Leningrad, 1987 (in Russ.).

\section{Events}

\section{$4^{\text {th }}$ WATER RESEARCH CONFERENCE: THE ROLE OF WATER TECHNOLOGY INNOVATION IN THE BLUE ECONOMY}

(10-13 September 2017, Crowne Plaza Kitchener-Waterloo)

Information: https://www.elsevier.com/events/conferences/water-research-conference 